\title{
FLOTATION OF ALUMINA FROM GIBBSITE BEARING-SHALE OF SOUTH WESTERN SINAI, EGYPT BY USING SODIUM DODECYL SULFATE
}

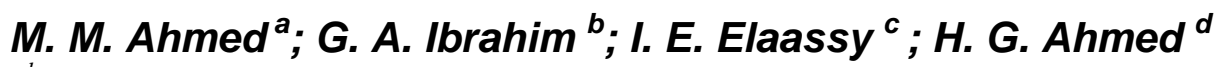 \\ ${ }^{a, b}$ Mining and Metallurgical Engineering Department, Faculty of \\ Engineering, Assiut University, Assuit 71516, Egypt \\ ${ }^{c, d}$ Nuclear Materials Authority, Egypt
}

(Received December 12, 2007 Accepted January 8, 2008)

\begin{abstract}
Samples of gibbsite bearing-shale of south western Sinai, Egypt were studied to upgrade the low grade alumina. The assays of the samples are about $18.98 \% \mathrm{Al}_{2} \mathrm{O}_{3}, 15.45 \% \mathrm{SiO}_{2}, 12.83 \% \mathrm{Fe}_{2} \mathrm{O}_{3}, 14.87 \% \mathrm{CaO}, 5.74 \%$ $\mathrm{P}_{2} \mathrm{O}_{5}, 5.34 \% \mathrm{MnO}, 0.86 \% \mathrm{~K}_{2} \mathrm{O}, 0.76 \% \mathrm{Na}_{2} \mathrm{O}, 1.50 \%$ trace elements and $23.65 \%$ loss on ignition. The aim of upgrading alumina in the concentrate is to make it suitable for the different industrial uses. Sodium dodecyl sulfate (an anionic collector) is effective in the acidic pH range. Below the isoelectric point of gibbsite where the alumina is positively charged, the sodium dodecyl sulfate was good at $\mathrm{pH}$ value of 2.

Under appropriate conditions (collector dosage $=800 \mathrm{~g} / \mathrm{t}$, pulp density $=300 \mathrm{~g} / \mathrm{l}$ and particle size $=-100+80 \mu \mathrm{m})$ and at $\mathrm{pH}=2, \quad$ a concentrate containing $39.5 \%$ alumina at component recovery of $96.9 \%$ and mass recovery of $52.8 \%$ was obtained. At these conditions, the assays of other ore constituents in the final concentrate are as follows: $\mathrm{SiO}_{2}$ was decreased from $14.2 \%$ to $6.4 \%, \mathrm{CaO}$ was decreased from $14.1 \%$ to $5.2 \%$, $\mathrm{Fe}_{2} \mathrm{O}_{3}$ was decreased from $13.1 \%$ to $5.6 \%, \mathrm{P}_{2} \mathrm{O}_{5}$ was decreased from $4.3 \%$ to $3.8 \%$, $\mathrm{MnO}$ was decreased from $4.2 \%$ to $3.2 \%$, while $\mathrm{K}_{2} \mathrm{O}$ was increased from $0.89 \%$ to $1.2 \%, \mathrm{Na}_{2} \mathrm{O}$ was increased from $0.69 \%$ to $1.1 \%$, traces was increased from $1.6 \%$ to $2.6 \%$, and loss on ignition was increased from $25.4 \%$ to $31.2 \%$. The component recoveries of $\mathrm{SiO}_{2}, \mathrm{CaO}$, $\mathrm{Fe}_{2} \mathrm{O}_{3}, \mathrm{P}_{2} \mathrm{O}_{5}, \mathrm{MnO}, \mathrm{K}_{2} \mathrm{O}, \mathrm{Na}_{2} \mathrm{O}$, and traces in the final concentrate were $23.8 \%, 19.5 \%, 22.6 \%, 46.6 \%, 40.2 \%, 39.1 \%, 33.1 \%$, and $85.8 \%$, respectively.
\end{abstract}

KEYWORDS: Gibbsite, alumina flotation, collectors, isoelectric point, pH, pulp density, particle size

\section{INTRODUCTION}

Aluminum is as considered the third most abundant element in the earth's crust and is one of the most commonly used metallic elements in civilization [1,2]. Aluminum alloys are used as a major structural material in aircraft, buildings, machinery parts, beverage cans and food warps [3]. This may be due to their high corrosion resistance and mechanical strength to mass ratio. In nature, aluminum occurs only in combination with other elements and is a part of the crystal structure of many rock forming minerals. Bauxite is the most important commercial ore of aluminum [4]. It consists of mixtures of aluminum hydroxide minerals and impurities [1]. 


\section{NOMENCLATURE}

$$
\begin{aligned}
& \mathrm{R}_{\mathrm{c}}(\mathrm{t})=\text { component recovery of } \\
& \text { constituent in tailings, } \% \\
& \mathrm{R}_{\mathrm{m}}(\mathrm{c})=\text { mass recovery of concentrate, } \% \\
& \mathrm{R}_{\mathrm{m}}(\mathrm{t})=\text { mass recovery of tailings, } \% \\
& \mathrm{t}=\text { assay of constituent in tailings, } \% \\
& \mathrm{~T} \quad=\text { mass of tailings, gm }
\end{aligned}
$$

$\mathrm{c}=$ assay of constituent in concentrate, $\%$

$\mathrm{C}=$ mass of concentrate, $\mathrm{gm}$

$\mathrm{f} \quad=$ assay of constituent in feed, $\%$

$\mathrm{F} \quad=$ mass of feed, gm

$\mathrm{R}_{\mathrm{c}}(\mathrm{c})=$ component recovery of constituent in concentrate, $\%$

The three aluminous minerals that form bauxite are boehmite $(\gamma \mathrm{AlO} . \mathrm{OH})$, gibbsite $(\mathrm{Al}(\mathrm{OH}) 3)$, and diaspore $(\alpha \mathrm{AlO} . \mathrm{OH})$ [1]. Besides of its main use as an aluminum ore, bauxite is used also to manufacture refractory products, aluminous chemicals, abrasives, and miscellaneous applications. These applications include $\beta$-alumina solid state electrolytes and first-class refractories [3].

The major impurities of gibbsite of south western Sinai are quartz, hematite and kaolinite. Other impurities such as, rare earths and alkali occur in small percentages. Gravity, magnetic, or electrostatic separation methods are not suitable for the concentration of gibbsite ore. This may be due to the very small significant differences in the physical properties (density, magnetic and electrostatic susceptibility, etc.) between the mineral phases (gibbsite, kaolinite and quartz), which are considered the major constituents of the ore. Flotation process was then selected as a suitable and effective method for the concentration and upgrading of alumina from gibbsite bearing-shale of south western Sinai to make it suitable for the Bayer process.

Many researchers [3-12] have studied the flotation of alumina using different types of collectors. The results are summarized as follows.

Bench scale experiments were used for the flotation of gibbsite/ kaolinite from quartz (Brazilian bauxite ore) using alkyl sulfates as collectors. The results were good at $\mathrm{pH} 2$, where the component recovery of alumina was $97.4 \%$ and the grade of alumina was $93 \%$ at a particle size of $(-177+3) \mu \mathrm{m}$ and a pulp density of $20 \%$ solids [3]. In other research, gibbsite was floated with sodium oleate from a mixture of quartz, kaolinite, iron and titanium oxides (Guyana bauxite ore) at $\mathrm{pH}$ values between $\mathrm{pH} 10$ and $\mathrm{pH}$ 11. The conditions were determined at which froth flotation resulted a component recovery more than $90 \%$ of the gibbsite [5]. During the adsorption of laurylamine on gibbsite, chamosite and boehmite, it was found that the maximum floatability of all minerals was achieved at $\mathrm{pH} 8$ and the adsorption of laurylamine occurred at a $\mathrm{pH}$ value ranged from 4 to 8 [6].

However, the flotation of gibbsite using amines as collectors can not be applied for the South Western Sinai gibbsite ore because of the presence of a significant amount of quartz. In the flotation of alumina from kyanite ore using different collectors, Bulut and Yurtsever [7] found that sodium dodecyl sulfate, as an alkyl sulfate collector, is effective in the acidic $\mathrm{pH}$ ranges. Dodecylamine hydrochloride (DAH), as a cationic collector, is effective in the basic $\mathrm{pH}$ range and potassium oleate (KOL), as an anionic collector, floats kyanite at $\mathrm{pH}$ value ranges from 6 to 9. In another study on the adsorption of cationic and anionic collectors on alumina surface, it was found that, in the case of using dodecylamine chloride (DDA) which is a cationic collector, the contact angles of water \& alumina, at $\mathrm{pH}$ value larger than 10.5 
was increased and hence hydrophobicity was enhanced. In the case of using anionic surfactant solutions, the contact angle of water \& alumina, at $\mathrm{pH}$ value lesser than 9, was increased with increasing the concentration of sodium dodecyl sulfate and hence, enhanced the hydrophobicity of alumina surface [8].

Diasporic-bauxite was floated from silicates by using quaternary ammonium salt (DTAL) at a $\mathrm{pH}$ value ranged from 6 to 7 [9]. The surface charges of gibbsite particles were probed by potentiometric titration and subsequently analyzed to estimate intrinsic proton affinity constants of $\mathrm{OH}$ surface groups. It was found that the point of zero charge could be achieved at a $\mathrm{pH}$ value ranged from 8.1 to 9.6 [10]. The electron spin resonance (ESR) was used to study the adsorption of spin probe analogs of stearic acid on amorphous alumina [11].

The point of zero charge (ZPC) of gibbsite at a $\mathrm{pH}$ value equals to 9.1. The electrokinetic potential and contact angle measurements were used to show the adsorption mechanism of sodium dodecyl sulfate and dodecylamine chloride on the alumina surface. From these results, it was found that, sodium dodecyl sulfate and dodecylamine chloride converted the alumina surface to a hydrophobic one at a $\mathrm{pH}$ less than ZPC and a pHmore than ZPC, respectively [12]. Zhenghe et al. [4] have used the reverse flotation technology to float alumina from alumino silicates using a cationic collector. The purpose of this paper is to determine the optimum conditions of flotation process to upgrade the alumina in gibbsite ore to make it suitable for industrial purposes, such as aluminous chemicals, abrasives, building stones, road surfacing, and alumina refractories [3].

\section{MINERALOGY}

Based on petrography and EDX technique, several minerals were identified in the studied samples as follows:

Gibbsite is turbid cryptocrystalline heavily stained black, orange and brown colors. It occurs as radial aggregate embedded in marly matrix. The matrix is mainly composed of equal amounts of fine-grained quartz and carbonate. It contains minute grains of Fe and Mn oxy-hydraoxides. The BSE of gibbsite is shown in Fig. 1.

Quartz is monocrystalline, medium-grained, well sorted and subround to well round. The cryptocrystalline quartz occurs as filling pore spaces between grains and as over growths. The BSE of qurrtz is shown in Fig. 2.

Kaolin occurs as amorphous dusts and patches with aggregate polarization in crossed nicols. It mostly resulted from acidic ground water whereas the unstable minerals dissolve releasing $\mathrm{Si}, \mathrm{Al}$ to the pore waters that can be produced by flushing of the gibbsite by fresh water. The BSE of kaolin is shown in Fig. 3.

Halite appears as disseminated small cubic crystals encountered in gibbsite. Calcite occurs as rhombohedral crystals, anhedral grains and aggregates radiating fibrous. It exhibits twinning and perfect rhombohedral cleavages.

Hematite occurs either as disseminated anhedral crystals or occasionally as minutes. It is steel-black with metallic luster in reflected light with a tendency to a marginal red. Generally, the iron is associated with manganese forming $\mathrm{Mn}-\mathrm{Fe}$ minerals.

Gypsum exists as white massive and acicular prismatic crystals of different shape and sizes. They exhibit aggregates of subhedral to anhedral crystals having 
vitreous luster. Few crystals show the perfect cleavage of the growing crystals. The occurrence of the gypsum in the studied gibbsite can be explained by the upward movement of brine by capillary action and its evaporation at the surface.

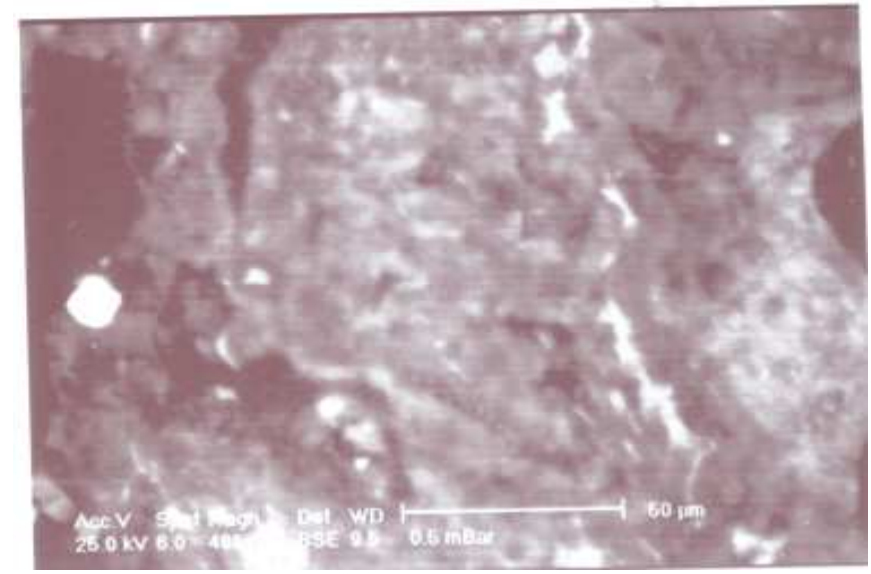

Fig. 1: The BSE image of gibbsite

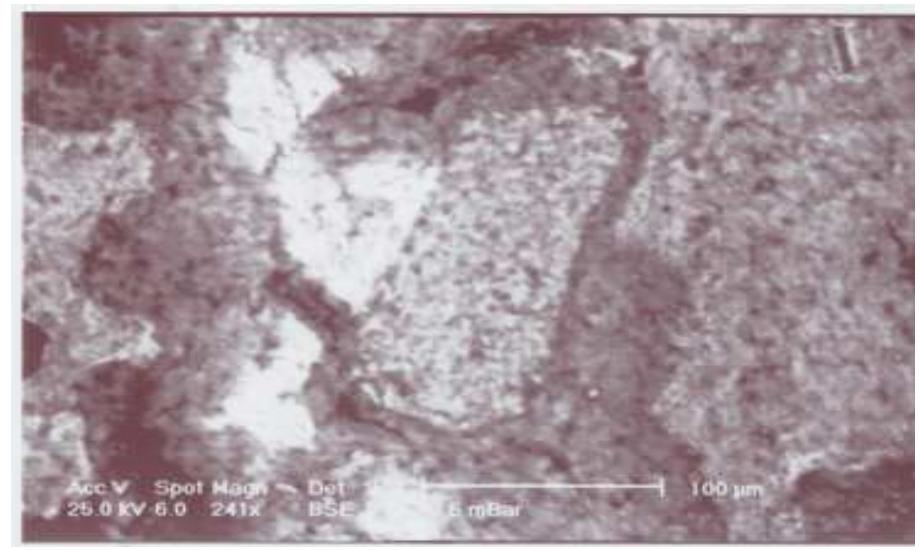

Fig. 2: The BSE image of quartz

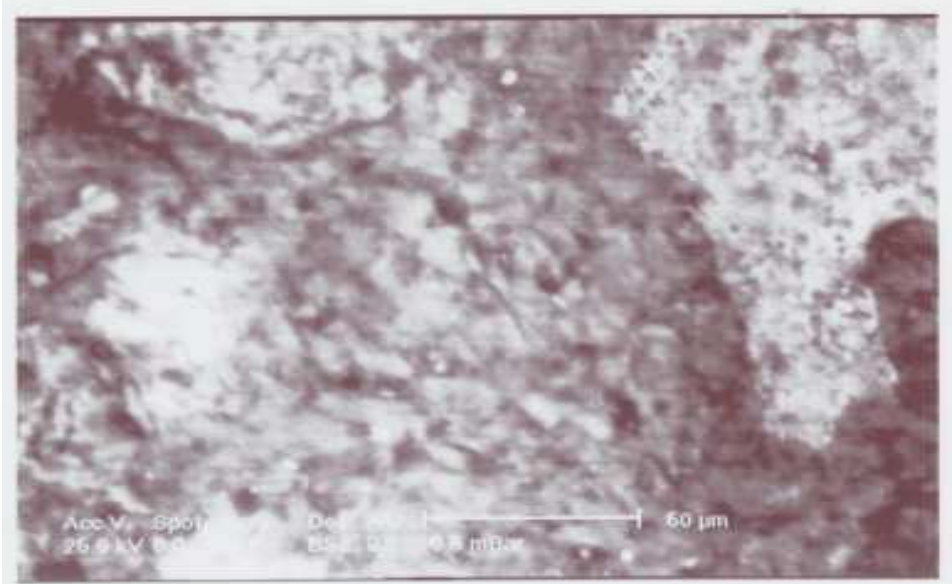

Fig. 3: The BSE image of kaolin 


\section{EXPERIMENTAL WORK}

\subsection{Materials}

The samples used in this present work were obtained from the Southwest of Sinai (Abu Thur). A batch representative sample of about $250 \mathrm{~kg}$ was taken from the gibbsite zone. The obtained sample was split to smaller ones and crushed to minus $10 \mathrm{~mm}$ in a laboratory jaw crusher. The crusher product was sieved on a screen of $200 \mu \mathrm{m}$ size. The screen oversize $(+200 \mu \mathrm{m})$ was ground in a closed circuit ball mill to minus 200 $\mu \mathrm{m}$. Grinding conditions were as follows: slope of mill $=0^{\circ}$, ball-to-ore ratio $=3: 1$, mill speed $=60 \mathrm{rpm}$, and grinding time $=20$ minutes. The crushing and grinding flowsheet of the head sample is illustrated in Fig. 4.

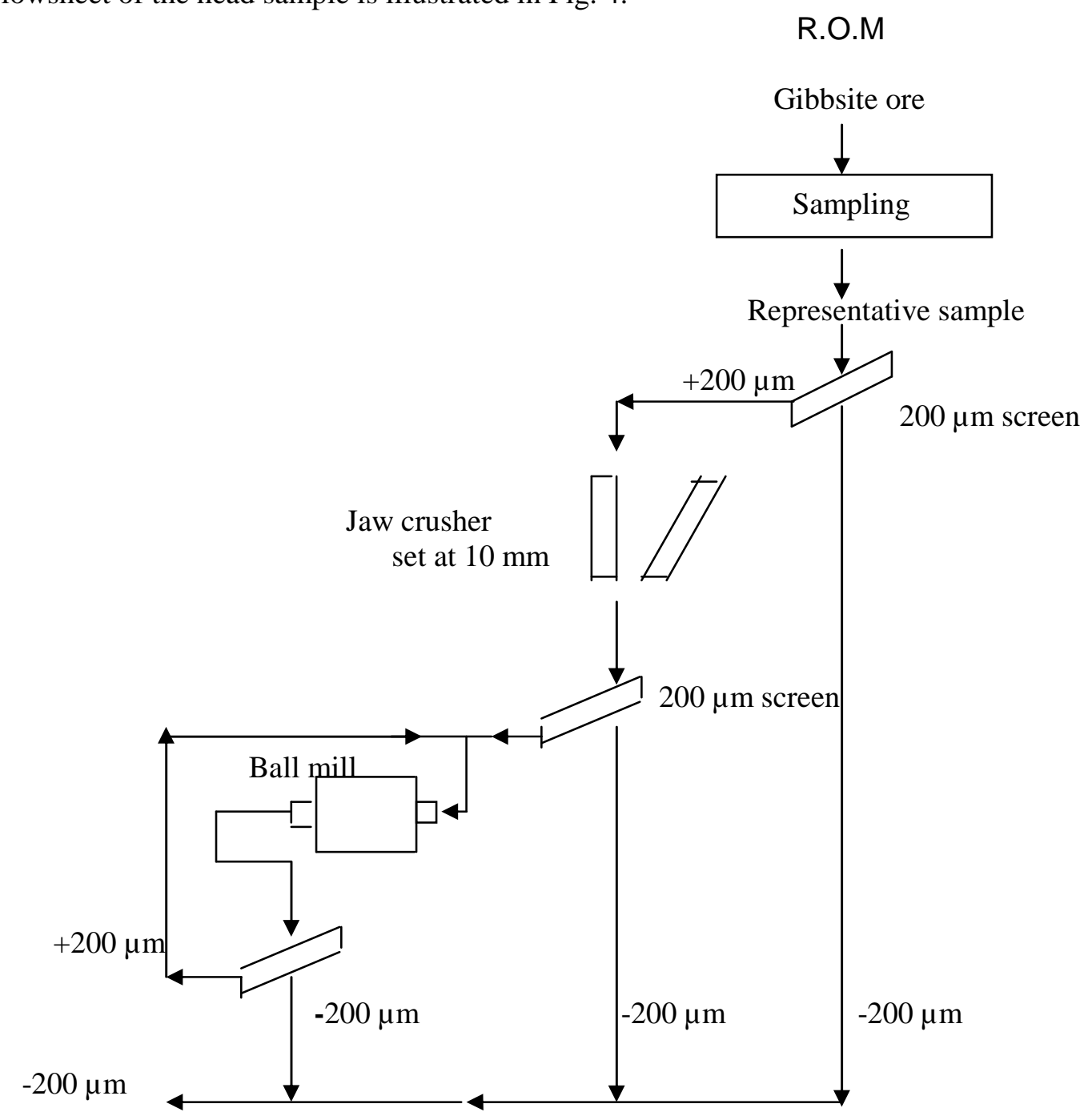

To flotation process 
Fig. 4: Crushing \& grinding flow-sheet of the head sample

A representative sample was taken and chemically analyzed for the determination of the different constituents. The chemical analysis of the studied head sample is given in Table 1.

Table 1: Chemical analysis of the head sample of gibbsite ore from South Western Sinai (Abuthur)

\begin{tabular}{|l|l|l|l|l|l|l|l|l|l|l|}
\hline $\mathbf{A l}_{2} \mathbf{O}_{3}$ & $\mathbf{S i O}_{2}$ & $\mathbf{F e}_{2} \mathbf{O}_{3}$ & $\mathbf{C a O}$ & $\mathbf{P}_{2} \mathbf{O} 5$ & $\mathbf{M n O}$ & $\mathbf{K}_{2} \mathbf{O}$ & $\mathbf{N a}_{2} \mathbf{O}$ & Traces & L.O.I. & Total \\
\hline 18.98 & 15.45 & 12.83 & 14.87 & 5.74 & 5.34 & 0.86 & 0.76 & 1.50 & 23.65 & 99.98 \\
\hline
\end{tabular}

\subsection{Reagents}

All flotation tests were carried out using sodium dodecyl sulfate as a collector, while hydrochloric acid was used as $\mathrm{pH}$ modifier. Tap water used for maintaining the flotation pulp at a constant level, as well as, all the other experimental purposes.

\subsection{Apparatus}

Laboratory flotation tests were carried out in a $3000 \mathrm{ml}$ Wemco Fagergern cell. A hand skimming was used to skim the froth.

\subsection{Experimental Procedures}

The impeller speed, during all flotation tests, was fixed at $1250 \mathrm{rpm}$ and an aeration rate of $6 \mathrm{~L} / \mathrm{min}$ was used. The total conditioning time was $15 \mathrm{~min}$. The studied operating parameters were the $\mathrm{pH}$ value, collector dosage, pulp density and particle size. The gibbsite sample was added slowly and then conditioned with water for 5 minutes.

The $\mathrm{pH}$ value was adjusted at the end of the initial conditioning period and allowed to condition for 5 minutes with the pulp. The collector dosage was added at the end of the second conditioning period and was allowed to condition for 5 min with the pulp prior to the aeration. The air supply valve was gradually opened. The required pulp level was maintained constant during the flotation experiments.

In each experiment, and after allowing $15 \mathrm{sec}$ for the froth to form, the concentrate was collected during batch flotation tests. The collected products (concentrate and tailings) were dried, weighed and chemically analyzed. The component recovery of alumina and other constituents in the concentrate and tailings were calculated.

\section{RESULTS AND DISCUSSION}

\subsection{Calculations of Experimental Mass and Component Recovery of Flotation products}

Using the mass percent and assays of alumina in feed, concentrate, and tailings, the experimental value of the mass recovery and component recovery of alumina in concentrate and tailings can be calculated as follows:

Mass recovery of concentrate $=\mathrm{R}_{\mathrm{m}}(\mathrm{c})=100 \cdot \frac{\mathrm{C}}{\mathrm{F}}$ 
Mass recovery of tailings $=R_{m}(t)=100 \cdot \frac{T}{F}$

Component recovery in concentrate $=R_{c}(c)=100 . \frac{\text { C.c }}{\text { F.f }}$

Component recovery in tailings $=\mathrm{R}_{\mathrm{c}}(\mathrm{t})=100 \cdot \frac{\text { T.t }}{\text { F.f }}$

\subsection{Results of Using Sodium Dodecyl Sulfate as a Collector}

\subsubsection{Effect of $\mathrm{pH}$ value}

Table 2 and Figure 5a show the effect of $\mathrm{pH}$ value on the alumina content, the component recovery of alumina in the concentrate, and mass recovery of concentrate. These experiments were executed at a particle size of $-200 \mu \mathrm{m}$, pulp density of $150 \mathrm{~g} / \mathrm{l}$, and collector dosage of $800 \mathrm{~g} / \mathrm{t}$. From this figure, it is noticed that the best selectivity was achieved at a $\mathrm{pH}$ value of 2 , where the component recovery of alumina in the concentrate was $64.2 \%$, the grade was $35.5 \%$, and mass recovery of concentrate was about $34.3 \%$.

Table 2: The effect of $\mathrm{pH}$ value on the grade, component recovery of alumnia, and the mass recovery.

\begin{tabular}{|c|c|c|c|c|c|}
\hline \multirow[b]{2}{*}{ Exp. No. } & \multirow[b]{2}{*}{ pH value } & \multirow[b]{2}{*}{ Product } & \multirow{2}{*}{$\begin{array}{c}\text { Mass } \\
\text { Recovery, \% }\end{array}$} & \multicolumn{2}{|c|}{ Alumina, $\%$} \\
\hline & & & & Grade & Recovery \\
\hline & & Concentrate & 34.3 & 35.5 & 64.2 \\
\hline 1 & 2 & $\begin{array}{l}\text { Tailings } \\
\text { Feed }\end{array}$ & $\begin{array}{l}65.7 \\
100\end{array}$ & $\begin{array}{c}10.4 \\
19\end{array}$ & $\begin{array}{c}35.8 \\
100\end{array}$ \\
\hline & & Concentrate & 29.9 & 34.5 & 54.2 \\
\hline 2 & 4 & $\begin{array}{l}\text { Tailings } \\
\text { Feed }\end{array}$ & $\begin{array}{l}70.1 \\
100\end{array}$ & $\begin{array}{c}12.4 \\
19\end{array}$ & $\begin{array}{l}45.8 \\
100\end{array}$ \\
\hline & & Concentrate & 28.1 & 31.1 & 46.1 \\
\hline 3 & 6 & $\begin{array}{l}\text { Tailings } \\
\text { Feed }\end{array}$ & $\begin{array}{l}71.9 \\
100\end{array}$ & $\begin{array}{c}14.3 \\
19\end{array}$ & $\begin{array}{c}53.9 \\
100\end{array}$ \\
\hline & & Concentrate & 26.6 & 29.9 & 41.8 \\
\hline 4 & 8 & $\begin{array}{l}\text { Tailings } \\
\text { Feed }\end{array}$ & $\begin{array}{c}73.4 \\
100 \\
\end{array}$ & $\begin{array}{c}15.1 \\
19 \\
\end{array}$ & $\begin{array}{r}58.2 \\
100 \\
\end{array}$ \\
\hline & & Concentrate & 31.6 & 32.2 & 53.5 \\
\hline 5 & 10 & $\begin{array}{l}\text { Tailings } \\
\text { Feed }\end{array}$ & $\begin{array}{c}68.4 \\
100\end{array}$ & $\begin{array}{c}12.9 \\
19\end{array}$ & $\begin{array}{l}46.5 \\
100\end{array}$ \\
\hline & & Concentrate & 33.6 & 30.1 & 53.2 \\
\hline 6 & 12 & $\begin{array}{l}\text { Tailings } \\
\text { Feed }\end{array}$ & $\begin{array}{c}66.4 \\
100\end{array}$ & $\begin{array}{c}13.4 \\
19\end{array}$ & $\begin{array}{c}46.8 \\
100\end{array}$ \\
\hline
\end{tabular}


The grade of alumina was decreased from $35.5 \%$ at a pH value of 2 to $29.9 \%$ at a $\mathrm{pH}$ value of 8 , and then increased at higher $\mathrm{pH}$ values. The selectivity decreased significantly when the $\mathrm{pH}$ value approached the gibbsite point of zero charge value which occurred at a $\mathrm{pH}$ value of (8.1-9), then increased again at higher $\mathrm{pH}$ values.

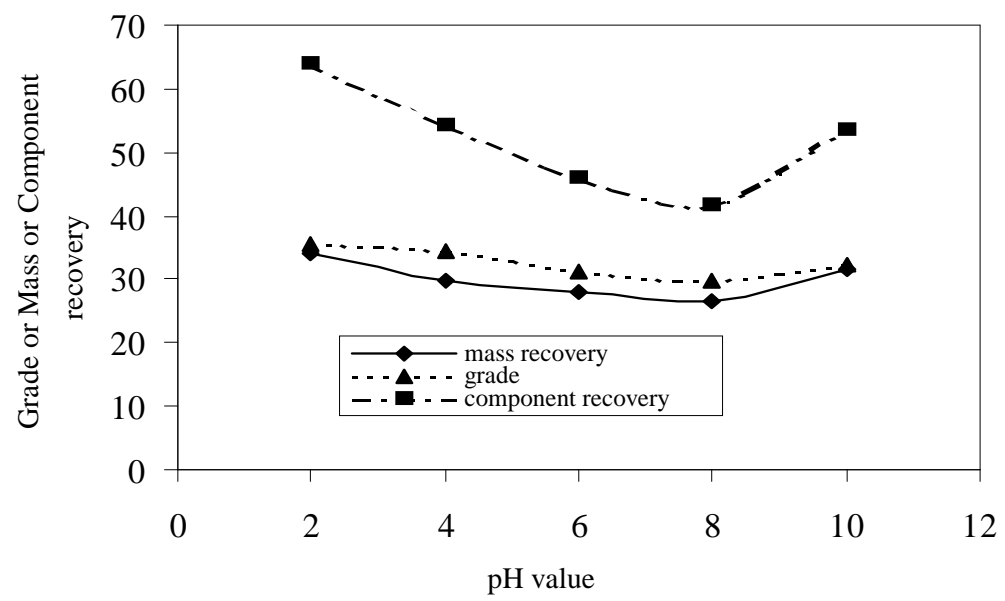

Fig. 5a: Effect of $\mathrm{pH}$ value on the grade, component recovery of alumina in the concentrate, and the mass recovery of concentrate.

Sodium dodecyl sulfate (alkyl sulfate) is an anionic collector and is effective in the acidic $\mathrm{pH}$ range. This collector is adsorbed on alumina by means of electrostatic and hydrophobic bonding [8]. Alumina is positively charged in pure water till a $\mathrm{pH}$ reaches a value of (8.1-9), after which charge reversal occurs [12]. Addition of sodium dodecyl sulfate converts the positive value of zeta potential of alumina to a negative one at a $\mathrm{pH}$ value greater than 2 , so it is adsorbed on alumina surface in a significant amount at a $\mathrm{pH}$ value of 2 and makes the alumina surface more hydrophobic.

Figure $5 \mathrm{~b}$ shows the effect of $\mathrm{pH}$ value on the grade, component recovery of alumina in the tailings, and the mass recovery of tailings.

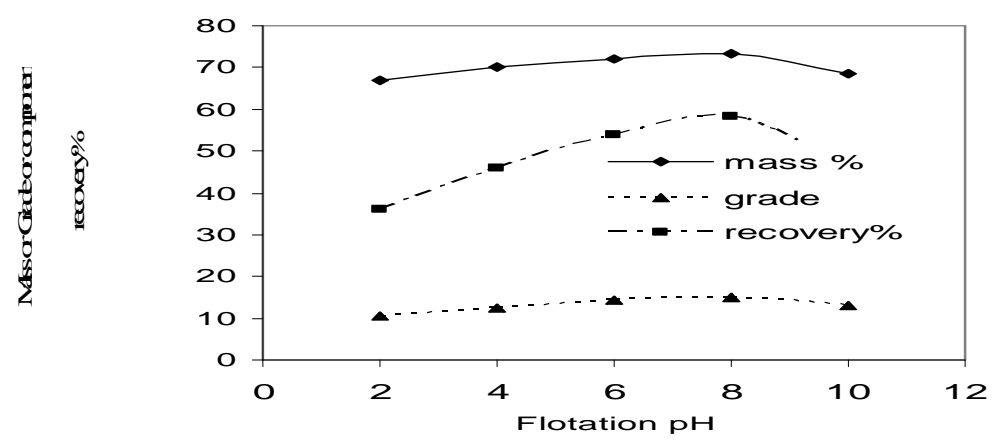

Fig. 5b: Effect of $\mathrm{pH}$ value on the grade, component recovery of alumina in tailings, and the mass recovery of tailings. 
From this figure it is shown that the component recovery of alumina in tailings increases from $\mathrm{pH}$ value of 2 to $\mathrm{pH}$ value of 8 where the best selectivity of alumina in the concentrate is at a $\mathrm{pH}$ value of 2 , while the least recovery of alumina in the concentrate is at $\mathrm{pH}$ value of 8 . At $\mathrm{pH}$ values greater than 8 , the component recovery of alumina in the tailings was decreased. The grade of alumina was increased from $10.4 \%$ at $\mathrm{pH}$ value of 2 to $15.1 \%$ at $\mathrm{pH}$ value of 8 , and then decreased at higher $\mathrm{pH}$ values.

\subsubsection{Effect of sodium dodecyl sulfate concentration}

Table 3 and Figure 6a show the effect of SDS concentration on the mass recovery, grade, and component recovery of alumina in the concentrate at the optimum value of $\mathrm{pH}$ (2) obtained from the previous experiments, which were carried out at the same conditions of pulp density and particle size. From Fig. 6a, it is clear that the component recovery of alumina increases from $64.2 \%$ at a concentration of $800 \mathrm{~g} / \mathrm{t}$ sodium dodecyl sulfate to about $73.5 \%$ at a dosage of $2800 \mathrm{~g} / \mathrm{t}$. The grade of alumina decreases from $35.5 \%$ to $27.2 \%$ at the same concentration. The mass recovery of concentrate increases from $34.3 \%$ to $51.8 \%$ at the same concentration.

At relatively low values of sodium dodecyl sulfate concentration, the individual sulfate ions are adsorbed as counter ions at the alumina surface. As the concentration of sodium dodecyl sulfate increases, the adsorption of sulfate ions increases and form a monolayer of the collector on the alumina surface, hence the recovery of alumina increases. An addition of higher concentrations of collector results in lower floatability.

Table 3: the effect of sodium dodecyl sulfate concentration on the mass recovery, grade, and component recovery of alumina

\begin{tabular}{|c|c|l|c||c|c|}
\hline $\begin{array}{c}\text { Exp. } \\
\text { No. }\end{array}$ & $\begin{array}{c}\text { Collector } \\
\text { dosage, } \mathbf{g} / \mathbf{t}\end{array}$ & Product & $\begin{array}{c}\text { Mass } \\
\text { Recovery, } \%\end{array}$ & \multicolumn{2}{|c|}{ Alumina, \% } \\
\hline \multirow{3}{*}{1} & \multirow{3}{*}{800} & Concentrate & 34.3 & 35.5 & Recovery \\
\hline & & Tailings & 65.7 & 10.4 & 35.8 \\
& & Feed & 100 & 19 & 100 \\
\hline \multirow{3}{*}{2} & \multirow{2}{*}{1200} & Concentrate & 38.9 & 31.5 & 64.5 \\
& & Tailings & 61.1 & 11 & 35.5 \\
& & Feed & 100 & 19 & 100 \\
\hline \multirow{3}{*}{3} & \multirow{2}{*}{1600} & Concentrate & 42.1 & 30.3 & 67.1 \\
& & Tailings & 57.9 & 10.8 & 32.9 \\
& & Feed & 100 & 19 & 100 \\
\hline \multirow{3}{*}{4} & \multirow{2}{*}{2400} & Concentrate & 49.4 & 27.2 & 70.8 \\
& & Tailings & 50.6 & 10.9 & 29.2 \\
& & Feed & 100 & 19 & 100 \\
\hline \multirow{3}{*}{5} & \multirow{2}{*}{2800} & Concentrate & 51.8 & 27 & 73.5 \\
& & Tailings & 48.2 & 10.4 & 26.5 \\
& & Feed & 100 & 19 & 100 \\
\hline
\end{tabular}




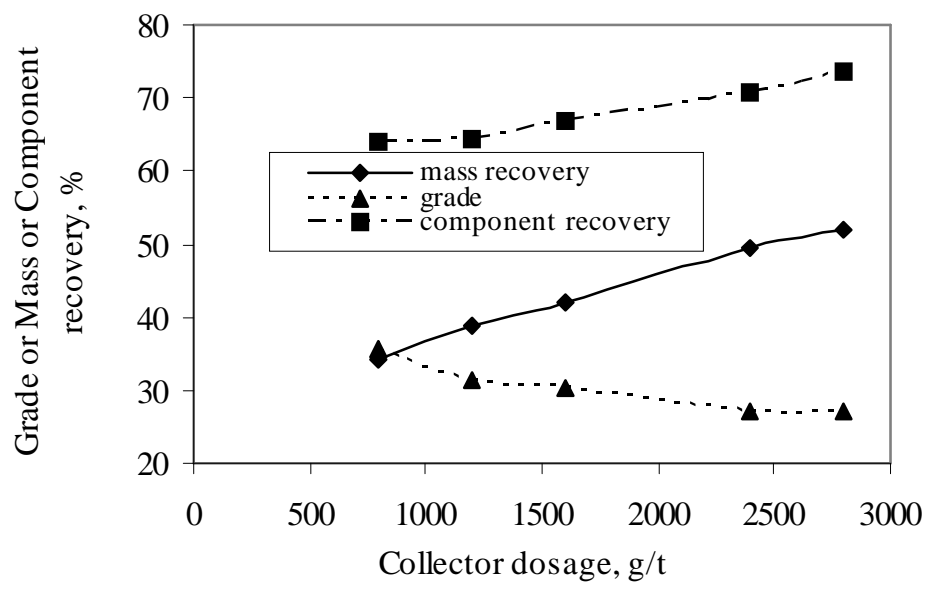

Fig. 6a: Effect of sodium dodecyl sulfate on the grade, component recovery of alumina in concentrate, and mass recovery of concentrate

At higher dosages of sodium dodecyl sulfate, the adsorption density of sulfate ions becomes sufficiently high, hence the interaction between hydrocarbon chains of sulfate ions occur through Van Der Waals forces. This phenomenon results in hemimiceles formation with the polar groups pointing towards the aqueous phase. The mineral surface, although coated with collector, becomes, therefore, hydrophilic and so the recovery of alumina decreases at higher collector concentrations [12-13-14].

Figure $6 \mathrm{~b}$ shows the effect of sodium dodecyl sulfate concentration on the grade, component recovery of alumina in the tailings, and the mass recovery of tailings. From this figure, it is seen that the component recovery of alumina in the tailings and the mass recovery of tailings decreases as the collector dosage increased. The component recovery of alumina in tailings decreases from $35.8 \%$ at a dosage of $800 \mathrm{~g} / \mathrm{t}$ to about $26.5 \%$ at a dosage of $2800 \mathrm{~g} / \mathrm{t}$ of sodium dodecyl sulfate.

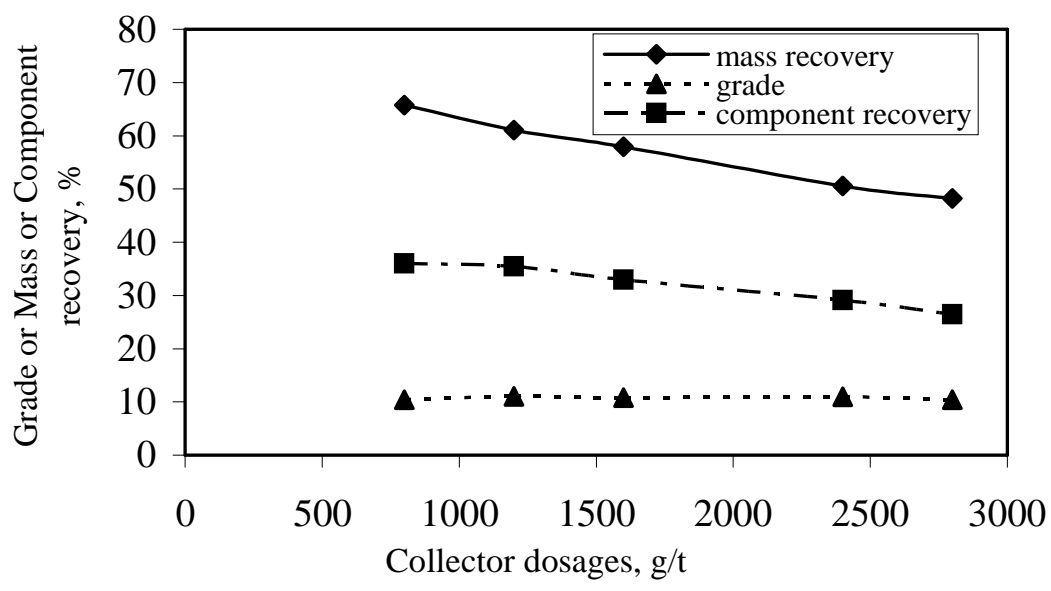

Fig. 6b: Effect of sodium dodecyl sulfate on the grade, component recovery of alumina in tailings, and mass recovery of tailings 
The mass recovery of tailings decreases from $65.7 \%$ to about $48.2 \%$ at the same conditions. From Fig. $6 b$, it is noticed also that the alumina content in tailings did not change with the increase of sodium dodecyl sulfate concentration.

\subsubsection{Effect of pulp density}

Table 4 and Figure 7a show the effect of pulp density on the grade, component recovery of alumina in the concentrate, and the mass recovery of the concentrate. These experiments were carried out at a $\mathrm{pH}$ value of $2,800 \mathrm{~g} / \mathrm{t}$ concentration of SDS, and with the same previous particle size. From Fig. 7a, it can be noticed that the component recovery of alumina increases from $75.4 \%$ at a pulp density of $200 \mathrm{~g} / \mathrm{l}$ to $94.1 \%$ at $350 \mathrm{~g} / \mathrm{l}$, then decreases to $90.3 \%$ at a pulp density of $400 \mathrm{~g} / \mathrm{l}$.

Table 4: The effect of pulp density on the mass recovery, grade, and component recovery of alumina

\begin{tabular}{|c|c|l|c|c|c|}
\hline \multirow{2}{*}{ Exp. No. } & \multirow{2}{*}{$\begin{array}{c}\text { Pulp } \\
\text { density, g/l }\end{array}$} & Product & Mass & \multicolumn{2}{|c|}{ Alumina, \% } \\
\cline { 5 - 6 } & & Recovery, \% & Grade & Recovery \\
\hline \multirow{3}{*}{1} & \multirow{3}{*}{200} & Concentrate & 33.9 & 42.4 & 75.4 \\
& & Tailings & 66.1 & 7.1 & 24.6 \\
& & Feed & 100 & 19 & 100 \\
\hline \hline \multirow{3}{*}{2} & \multirow{3}{*}{250} & Concentrate & 37.2 & 40.1 & 78.4 \\
& & Tailings & 62.8 & 6.6 & 21.6 \\
& & Feed & 100 & 19 & 100 \\
\hline \hline \multirow{3}{*}{3} & \multirow{3}{*}{300} & Concentrate & 44.9 & 37.5 & 88.8 \\
& & Tailings & 55.1 & 39 & 11.2 \\
& & Feed & 100 & 19 & 100 \\
\hline \multirow{3}{*}{4} & \multirow{3}{*}{350} & Concentrate & 63.4 & 28.2 & 94.1 \\
& & Tailings & 36.6 & 3.1 & 5.9 \\
& & Feed & 100 & 19 & 100 \\
\hline \hline \multirow{3}{*}{5} & \multirow{3}{*}{400} & Concentrate & 58.9 & 29.2 & 90.3 \\
& & Tailings & 41.1 & 4.5 & 9.7 \\
& & Feed & 100 & 19 & 100 \\
\hline
\end{tabular}

From this figure, it can be revealed that the grade of alumina decreases from $42.4 \%$ a a pulp density of $200 \mathrm{~g} / \mathrm{l}$ to $28.2 \%$ at $350 \mathrm{~g} / \mathrm{l}$, then increases to $29.2 \%$ at a pulp density of $400 \mathrm{~g} / \mathrm{l}$. The mass recovery of concentrate increases from $33.9 \%$ at a pulp density of $200 \mathrm{~g} / \mathrm{l}$ to $63.4 \%$ at $350 \mathrm{~g} / \mathrm{l}$, and then decreases to $58.9 \%$ at $400 \mathrm{~g} / \mathrm{l}$. The above obtained results assure that the pulp density has a great effect on the flotation of alumina. This behavior may be due to that, with the increase of the pulp density, both the retention time of pulp in the flotation machine and the volumetric reagent concentration increase. The increase in the pulp density increases the levitation by decreasing the effective gravitational pull on the particles and increases solution 
concentration with the collector addition and hence, increases reaction rate. The best results of the flotation are obtained at higher pulp densities. However, excessive pulp density will result in adverse effects such as, deterioration of the pulp aeration and floatability of large size particles, and increase the floatability of fine gangue particles, which result in reducing the quality of the concentrate $[15,16]$.

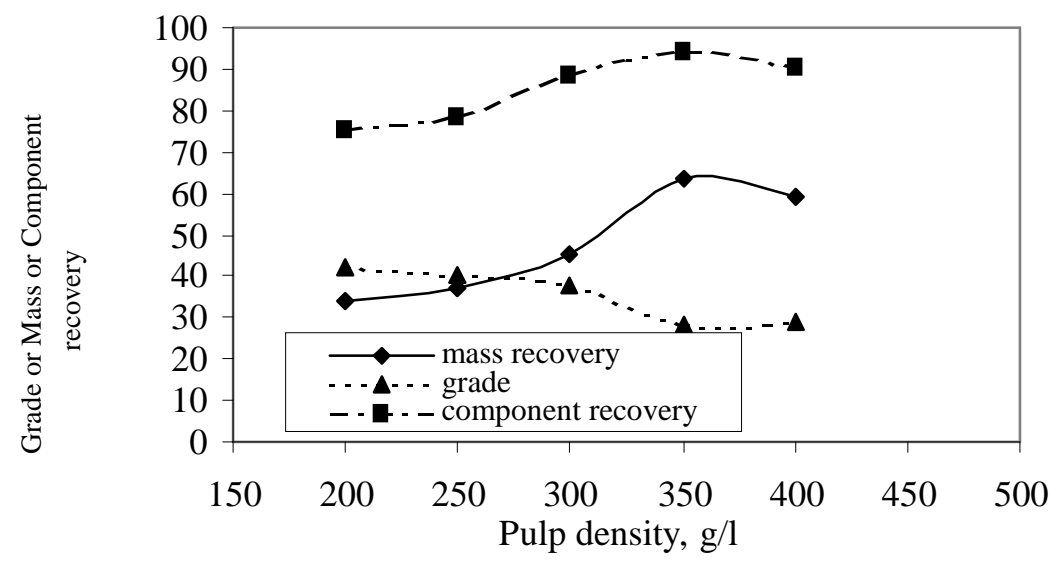

Fig. 7a: Effect of pulp density on the grade, component recovery of alumina in concentrate, and the mass recovery of concentrate.

Figure $7 \mathrm{~b}$ shows the effect of pulp density on the grade, component recovery of alumina in the tailings, and the mass recovery of tailings. From this figure, it is seen that the component recovery of the alumina in the tailings decreases from $24.6 \%$ at a pulp density of $200 \mathrm{~g} / \mathrm{l}$ to $5.9 \%$ at $350 \mathrm{~g} / \mathrm{l}$, then increases to $9.7 \%$ at a pulp density of $400 \mathrm{~g} / \mathrm{l}$. The mass recovery of tailings decreases from $66.1 \%$ to $36.6 \%$ at the same pulp densities, and then increases to $58.9 \%$ at $400 \mathrm{~g} / \mathrm{l}$. The grade of alumina decreases from $7.1 \%$ to $3.1 \%$ at the same pulp densities, and then increases to $4.5 \%$ at $400 \mathrm{~g} / \mathrm{l}$. The higher pulp density leads to appearance of a lower grade mineral in the concentrate and increases the recovery of alumina in tailings.

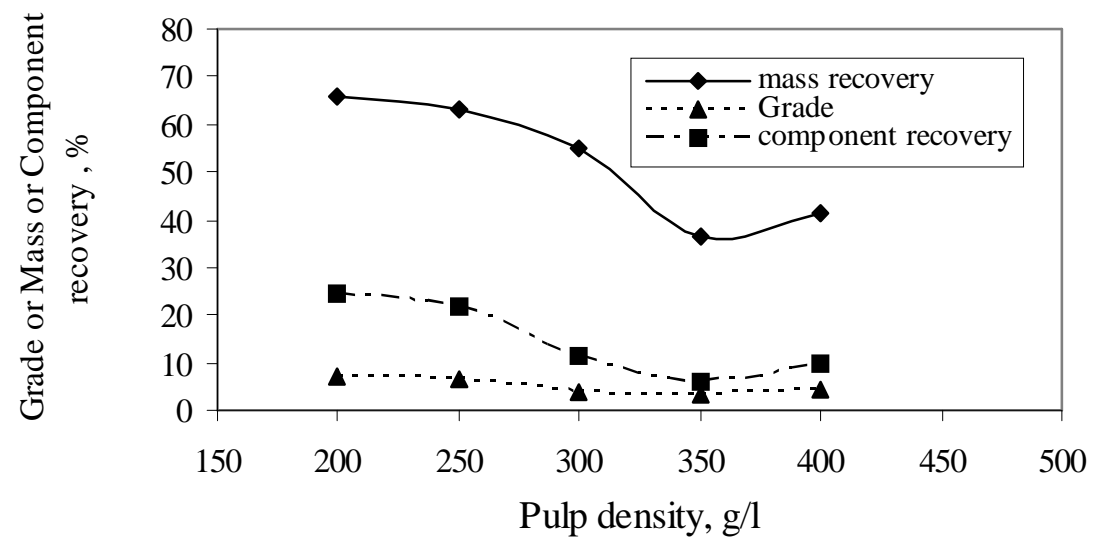

Fig. 7b: Effect of pulp density on the grade, component recovery of alumina in tailings, and the mass recovery of tailings. 


\subsubsection{Effect of particle size}

Table 5 and Figure 8a show the effect of particle size on the grade, component recovery of alumina in concentrate, and the mass recovery of concentrate. These experiments were executed at a pH value of $2,800 \mathrm{~g} / \mathrm{t}$ concentration of SDS, and a pulp density of $300 \mathrm{~g} / \mathrm{l}$. From Fig. 8a, it is shown that particles of various sizes did not float equally well. For coarse particles, the recovery decreases due to the incomplete liberation, very small contact angle, and very violent agitation. The component recovery of alumina increases from $57.8 \%$, at a particle size of $(-200+160) \mu \mathrm{m}$ to $97.9 \% \mu \mathrm{m}$ at $(-80+63) \mu \mathrm{m}$, and then decreases to $94.5 \%$ at $(-63+0) \mu \mathrm{m}$.

The mass recovery of concentrate increases from $19.9 \%$ to $65.1 \%$ at the same particle sizes, and then decreases to $59.2 \%$ at $(-63+0) \mu \mathrm{m}$. From Fig. $8 \mathrm{a}$, it can be also seen that the grade of alumina in concentrate decreases from $44.1 \%$ at a particle size of $(-200+160) \mu \mathrm{m}$ to $33.1 \%$ at $(-80+63) \mu \mathrm{m}$, and then increases to $33.5 \%$ at $(-63+0) \mu \mathrm{m}$.

Table 5: The effect of particle size on the mass recovery, grade, and component recovery of alumina

\begin{tabular}{|c|c|c|c|c|c|}
\hline \multirow{2}{*}{$\begin{array}{l}\text { Exp. } \\
\text { No. }\end{array}$} & \multirow{2}{*}{$\begin{array}{l}\text { Particle } \\
\text { size, } \mu \mathrm{m}\end{array}$} & \multirow{2}{*}{ Product } & \multirow{2}{*}{$\begin{array}{c}\text { Mass } \\
\text { Recovery, \% }\end{array}$} & \multicolumn{2}{|c|}{ Alumina, \% } \\
\hline & & & & Grade & Recovery \\
\hline \multirow{3}{*}{1} & \multirow{3}{*}{$-200+160$} & Concentrate & 19.9 & 44.1 & 57.8 \\
\hline & & Tailings & 80.1 & 8.1 & 42.2 \\
\hline & & Feed & 100 & 15.2 & 100 \\
\hline \multirow{3}{*}{2} & \multirow{3}{*}{$-160+125$} & Concentrate & 26.4 & 43.4 & 73.9 \\
\hline & & Tailings & 73.6 & 5.5 & 26.1 \\
\hline & & Feed & 100 & 15.5 & 100 \\
\hline \multirow{3}{*}{3} & \multirow{3}{*}{$-125+100$} & Concentrate & 40.2 & 41.8 & 92.3 \\
\hline & & Tailings & 59.8 & 2.3 & 7.7 \\
\hline & & Feed & 100 & 18.2 & 100 \\
\hline \multirow{3}{*}{4} & \multirow{3}{*}{$-100+80$} & Concentrate & 52.8 & 39.5 & 96.9 \\
\hline & & Tailings & 47.2 & 1.4 & 3.1 \\
\hline & & Feed & 100 & 21.5 & 100 \\
\hline \multirow{3}{*}{5} & \multirow{3}{*}{$-80+63$} & Concentrate & 65.1 & 33.1 & 97.9 \\
\hline & & Tailings & 34.9 & 1.3 & 2.1 \\
\hline & & Feed & 100 & 22 & 100 \\
\hline \multirow{3}{*}{6} & \multirow{3}{*}{$-63+0$} & Concentrate & 59.2 & 33.5 & 94.5 \\
\hline & & Tailings & 40.8 & 2.8 & 5.5 \\
\hline & & Feed & 100 & 21 & 100 \\
\hline
\end{tabular}

The particle size is known to be an important parameter for the high performance of the flotation process [17]. The component recovery decreases as the particle size increases, because the recovery rates of coarser particles are affected by disruption of particle-bubble aggregate in turbulent zones, as well as, a decrease in buoyancy of the particle bubble aggregate relative to the pulp [18]. From Fig. 8a, it 
can be seen that the component recovery of alumina and the mass recovery of concentrate are increased as the particle size is decreased. This increase is due to the increase of the liberated part of alumina in the feed. On the other hand, the grade of alumina in the concentrate decreased, as the particle size of $(-63+0) \mu \mathrm{m}$ contains fine and super fine particles.

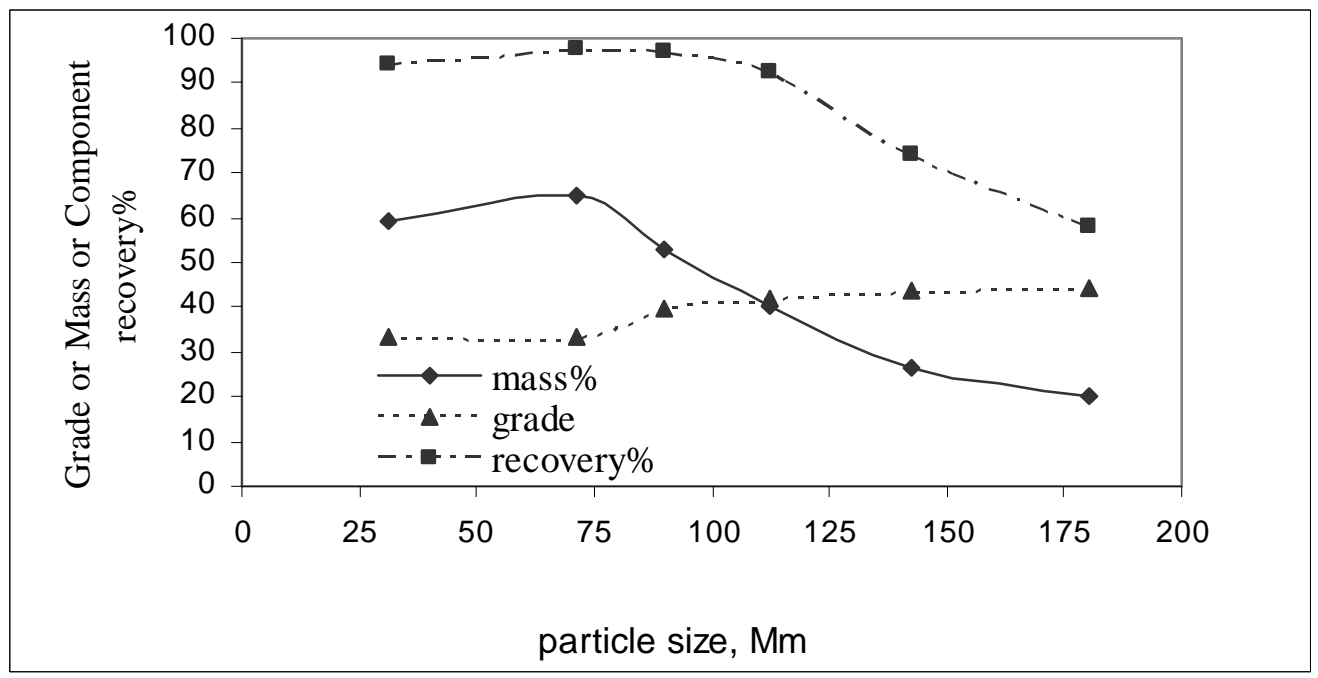

Fig. 8a: Effect of particle size on the grade, component recovery of alumina in concentrate, and the mass recovery of concentrate.

Fine particles are not only slow to float, but also they become almost unresponsive to reagents even to exorbitant quantities of reagents. At the same time, the gangue particles are activated till the difference in the response between valuable mineral and the gangue minerals is totally lost. The poor response of very fine particles in any flotation pulp seems to be ascribable not only to the poorer chance for mineral bubble encounter in the fine sizes, but also due to the fact that very fine particles have older surfaces than coarser ones, so fine sizes are extensively affected by ions derived from other minerals, by oxygen, or by water $[14,18]$.

Figure $8 \mathrm{~b}$ shows the effect of particle size on the grade, component recovery of alumina in the tailings, and the mass recovery of tailings. From this figure, it is revealed that the component recovery of alumina in tailings decreases from $42.2 \%$ at a particle size of $(-200+160) \mu \mathrm{m}$ to $2.1 \%$ at $(-80+63) \mu \mathrm{m}$, then increases to $5.5 \%$ at $(-63+0 \mu \mathrm{m})$. The mass recovery in the tailings decreases from $80.1 \%$ to $34.9 \%$ at the same particle sizes, then increases to $40.8 \%$ at a particle size of $(-63+0) \mu \mathrm{m}$. The grade of alumina in tailings decreases from $8.1 \%$ at a particle size of $(-200+160) \mu \mathrm{m}$ to $1.3 \%$ at $(-80+63) \mu \mathrm{m}$, then increases to $2.8 \%$ at $(-63+0) \mu \mathrm{m}$. From this figure, it can be also noticed that the rise of assays values in tailing in the coarser fractions might be due to a progressive decrease in the liberation and failure to float coarse free mineral. 


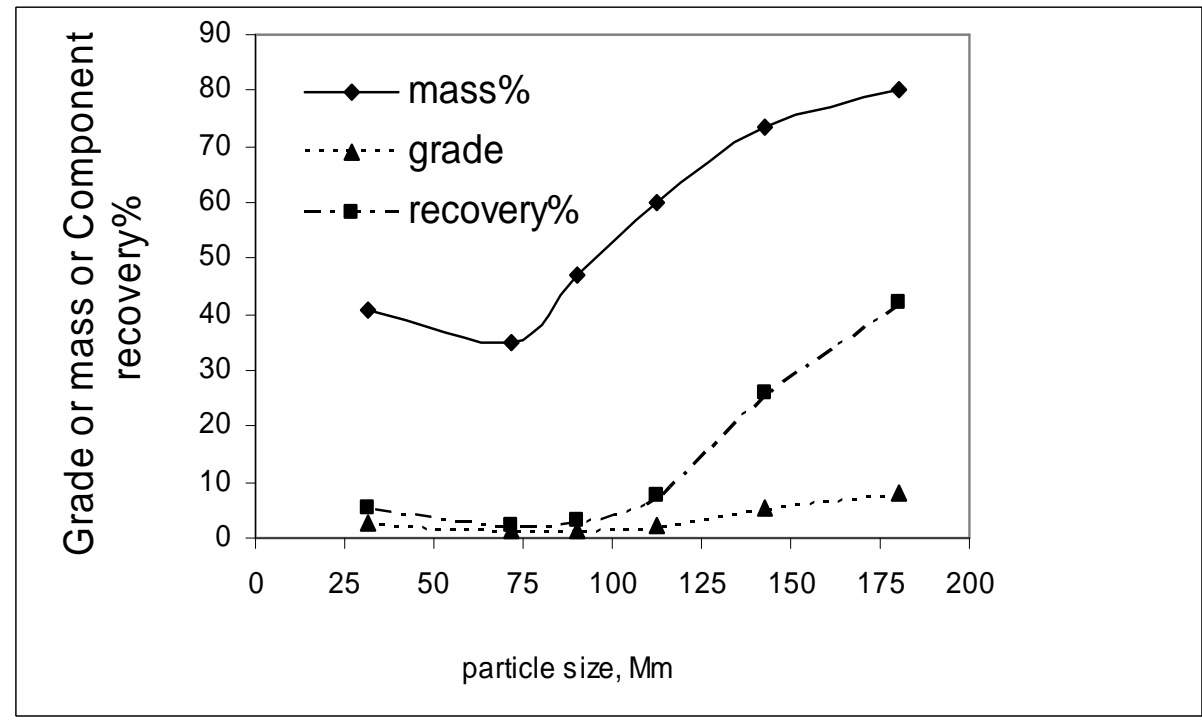

Fig. 8b: Effect of particle size on the grade, component recovery of alumina in tailings, and the mass recovery of tailings.

\section{CONCLUSIONS}

From the results and discussions in this research the following conclusions can be drawn:

1. Sodium dodecyl sulfate was used as an anionic collector. Cationic collectors can not be applied for the gibbsite ore under studied conditions due to the presence of significant amount of quartz.

2. The values of the studied parameters at the optimum conditions were as follows: $800 \mathrm{~g} / \mathrm{t}$ sodium dodecyl sulfate, pulp density $=300 \mathrm{~g} / \mathrm{l}, \mathrm{pH}$ value $=2$, and a particle size of $(-100+80) \mu \mathrm{m}$. Under these optimum values, a concentrate with a mass recovery of $52.8 \%$ containing $39.5 \% \mathrm{Al} 2 \mathrm{O} 3$ with an alumina recovery of $96.9 \%$ was obtained. The grades of other ore constituents in the final concentrate were as follows: $6.4 \% \mathrm{SiO} 2,5.2 \% \mathrm{CaO}, 5.6 \% \mathrm{Fe} 2 \mathrm{O} 3,3.8 \% \mathrm{P} 2 \mathrm{O} 5,3.2 \% \mathrm{MnO}$, $1.2 \% \mathrm{~K} 2 \mathrm{O}, 1.1 \% \mathrm{Na} 2 \mathrm{O}, 2.6 \%$ traces, and $31.2 \%$ loss on ignition. The component recoveries of $\mathrm{SiO} 2, \mathrm{CaO}, \mathrm{Fe} 2 \mathrm{O} 3, \mathrm{P} 2 \mathrm{O} 5, \mathrm{MnO}, \mathrm{K} 2 \mathrm{O}, \mathrm{Na} 2 \mathrm{O}$, and traces in the final concentrate were $23.8 \%, 19.5 \%, 22.6 \%, 46.6 \%, 40.2 \%, 39.1 \%, 33.1 \%$, and $85.8 \%$, respectively.

3. The final obtained product is suitable for many industrial purposes such as aluminous chemicals (aluminum sulfate and sodium aluminate are used for water treatment and aluminum chloride is used in refining crude petroleum) and abrasive products (coated abrasives, sharpening stones and grinding wheels). The final product may be also suitable for alumina refractories and aluminium extraction after its processing by Bayer process. 


\section{REFERENCES}

1. Burkin, A.R., "Production of aluminum and alumina", John \& Sons, New York, pp. 3-13, 1987.

2. O'Connor, D.J., "Alumina extraction from non bauxitic materials", AluminumVerlag GmbH, Germany, pp. 1-10, 1988.

3. Bittencourt, L.R.M., Lin, C.L., and Miller, J.D., "Flotation recovery of high purity gibbsite concentrates from a Brazilian bauxite ore", In: Advanced MaterialsApplication Mineral and Metallurgical Processing Principles, Society of Mining Engineers of AIM, pp. 77-85, 1990.

4. Zhenghe, X., Plitt, V., and Liu, Q., "Recent advances in reverse flotation of diasporic ores-A Chinese experience", Minerals Engineering, Vol. 17, pp. 10071015, 2004.

5. Hinds, S.A., Husain, K., and Liu, N., "Beneficiation of bauxite tailings", Light Met., Vol. 54, pp. 17-30, 1985.

6. Andreev, P.I., Anishchenko, N.M., and Mishakenkova, N.P., "Mechanism of the action of amines during the flotation of bauxite ore minerals", Tsvetnye Metally, Vol. 18, pp. 13-17, 1975.

7. Bulut, G. and Yurtsever, C., "Flotation behaviour of bitlis kyanite ore", Int. J. Miner. Process. Vol. 73, pp. 29- 36, 2004.

8. Doss, S.K., "Adsorption of dodecyltrimethylammonium chloride on alumina and its relation to oil-water flotation", Min. Process. Extr. Metall., C195-C199, 1976.

9. Wang, Y., Hu, Y., He, P., and GU, G., "Reverse flotation of silicates from diasporic-bauxite", Minerals Engineering, Vol. 17, pp. 63-68, 2004.

10. Marie, C.J., Fabien, G., and Bernard, H., "Limitations of potentiometric studies to determine the surface charge of gibbsite $\gamma-\mathrm{Al}(\mathrm{OH}) 3$ particles", Journal of Colloid and Interface Science, Vol. 6, pp. 1-11, 2005.

11. Murray, B.M., "Adsorption of fatty acid spin probes on amorphous alumina", Journal of Colloid and Interface Science, Vol. 76, pp. 393-398, (1980).

12. Hu, Y. and Dai, J., "Hydrophobic aggregation of alumina in surfactant solution", Minerals Engineering, Vol. 16, pp. 1167-1172, 2003.

13. Somasunaran, P. and Huang, L., "Adsorption/aggregation of surfactants and their mixtures at solid-liquid interface", Advances in Colloid and Interface Science. Vol. 88, pp. 179-208, 2000.

14. Jain, S.K., "Mineral Processing", 2nd ed., CBS, New Delhi, pp. 248-260, 2001.

15. Vijayendra, H.G., "Handbook on mineral dressing", 2nd ed., Vikas, New Delhi, pp. 195-210, 1995.

16. Wills, B.A., "Mineral Processing technology", Elsevier Ltd., $7^{\text {th }}$ ed., pp. 283-293, 2006.

17. Vamvuka, D. and Agridiotis, V., "The effect of chemical reagents on lignite flotation", Int. J. Min. Process., Vol. 61, pp. 209-224, 2000.

18. Feng, D. and Aldrich, C., "Effect of particle size on flotation performance of complex sulfide ores", Minerals Engineering, Vol. 12, pp. 721-731, 1999. 


\section{تعويم الالومينا فى خام طقلة جنوب غرب سيناء الحامله للجبسيت باستخدام SODIUM DODECYL SULFATE}

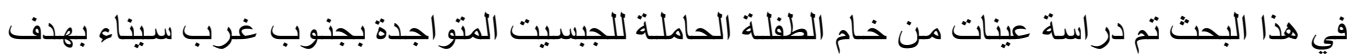

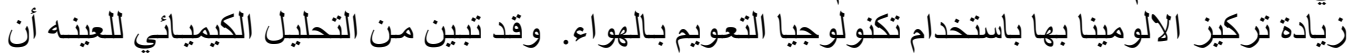
$\mathrm{CaO}=$ و ونسبة $\mathrm{Al}_{2} \mathrm{O}_{3}=18.98 \%$ و ونسبة $\mathrm{Fe}_{2} \mathrm{O}_{3}=12.83 \%$ و نسبة 14.87\% و نسبة $187 \%$ و و نسبة $\mathrm{P}_{2} \mathrm{O}_{5}=5.74 \%$ و

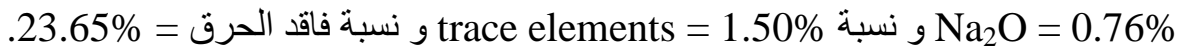
بهدف رفع تركيز الالومينا في خام الطفلة الحاملة للجبسيت إلي الحصول على منتج بمو اصفات مناسبة

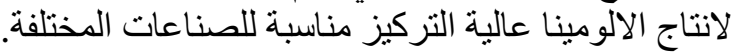
في هذا البحث تم استخدام Sodium dodecyl sulfate كمجمع وقد وجد من النتائج أن Sodium

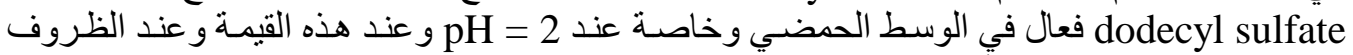

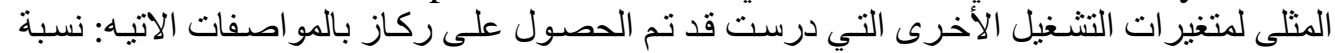

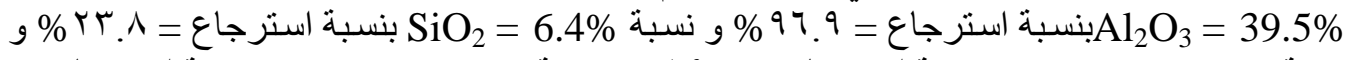
نسبة 7.

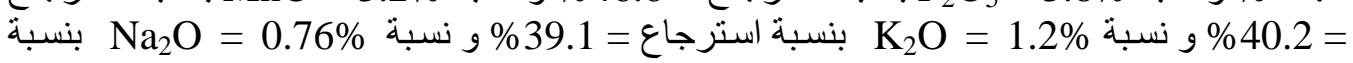

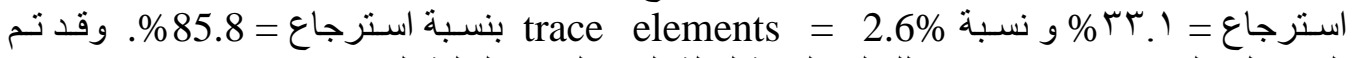
الحصول على 52.8\% استرجاع للكتله بالنسبة لكتلة الخام المغذى لخلية التعويم.

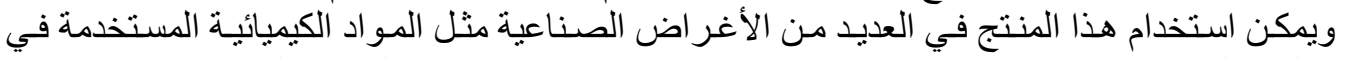

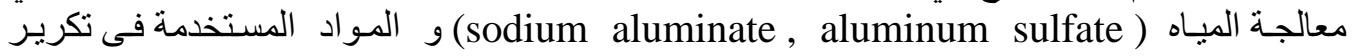

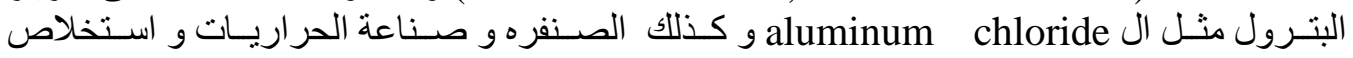
Bayer الالومنيوم بعد تركيز ها بطريقة من 